\title{
ALTERNATIF PENEGAKAN HUKUM DALAM PERSPEKTIF ISLAM
}

\author{
Tri Handayani \\ Dosen Fakultas Agama Islam \\ Universitas Wahid Hasyim Semarang \\ Trihandayani@gmail.com
}

\begin{abstract}
Abstrak
Hukum merupakan sarana untuk mengendalikan aktivitas kehidupan berbangsa dan bernegara. Oleh karena itu, penegakan hukum sangat didambakan masyarakat Indonesia saat ini. Namun untuk mewujudkan dambaannya, tidak cukup hanya dengan undang-undang belaka, tetapi harus memperhatikan tiga fenomena hukum, yaitu: substansi hukum, struktur hukum dan budaya hukum, dalam arti adanya konsistensi antara law in books dan law in action. Belum terwujudnya penegakan hukum di Indonesia disebabkan adanya tiga faktor yang menjadi kendala utama yaitu: 1) faktor kualitas hidup masyarakat, 2) faktor rumusan hukum, 3) faktor kualitas sumber daya manusia. Akibat tiga kendala tersebut, menjadi penyebab terpuruknua Indonesia disegala bidang. Untuk mengantisipasi keterpurukan yang dialami bangsa Indonesia sekarang, maka alternatif yang perlu dipertimbangkan adalah pendekatan agama dan moral, dalam arti pembinaan Akhlaqul Karimah.
\end{abstract}

Kata kunci: penegakan hukum, perspektif Islam

\begin{abstract}
Law means to control activities of nation and state life. Therefore, law enforcement is something longed for Indonesian people yet. However, to realize their dream, it is not enough to only rely on constitution, it should pay attention 3 phenomena of law, such as: substantial law, structure law, and culture law. Those means there are consistency between law in book and law in action. Not realizing law enforcement in Indonesia, it causes 3 factors which becomes the main problem such as: 1) quality of life factor, 2) legal formulation factor, 3) factor of human recources quality. The effect of 3 factors becomes Indonesia down in all fields. To anticipate the down of Indonesia yet, so the alternative to consider is religious and moral approach, it means guiding Akhlaqul Karimah.
\end{abstract}

Keyword: Law enforcement, Islamic perspective 


\section{PENDAHULUAN}

Kompleksnya permasalahan yang dihadapi masyarakat dewasa ini, mendesak diadakan suatu pengaturan hukum untuk menata dan mengendalikan aktivitas kehidupan bermasyarakat, berbangsa dan bernegara. Untuk maksud tersebut, dibutuhkan pula ketajaman visi bagi penentu dalam kebijakan politik (decision maker) dalam merancang dan membentuk politik yang sesuai budaya hukum masyarakat.

Hukum sebagai sarana rekayasa sosial (a tool of social engineering) perlu diberdayakan sedemikian rupa sehingga dapat terwujud supremasi hukum dalam kehidupan masyarakat. Dalam kaitan ini terdapat perbedaan dengan pandangan aliran hukum positif yang menganggap hukum tidak lain hanya kumpulan peraturan, tujuan hukum tidak lain dari sekedar menjamin terwujudnya kepastian hukum, karena aliran tersebut hanya melihat hukum dari segi apa yag seharusnya (das sollen), dan bukan pada kenyataan (das sein). ${ }^{1}$ Aliran hukum positif di atas banyak mempengaruhi pemikiran para penguasa (pemerintah), sehingga kadang mereka terlalu optimis bahwa semakin banyak peraturan akan semakin menjamin terwujudnya kepastian hukum. Namun dalam kenyataan, masih ditentukan adanya penyimpangan dalam bentuk Korupsi, Kolusi dan Nepotisme (KKN). Kondisi tersebut untuk jangka panjang dapat menurunkan kepercayaan masyarakat terhadap penegakan hukum dan lembaga-lembaga hukum. Bahkan dewasa ini muncul kesan di masyarakat, hukum hanya sebagai simbol belaka. Kesan (image) tersebut disebabkan karena supremasi hukum tidak dapat dilaksanakan sebagaimana mestinya. Oleh sebab itu, penegakan hukum merupakan masalah yang sangat didambakan masyarakat Indonesia dewasa ini.

Dambaan atas penegakan dalam makna supremasi hukum bukan sesuatu yang begitu gampang, karena supremasi hukum tidak mungkin

1 Ahmad Ali, Menguak Tabir Hukum (Suatu Kajian Filosofis dan Sosiologis), (Jakarta: Chandra Pratama, Cet.I, 1996), hlm.94. 
tercapai hanya dengan undang-undang belaka, tetapi harus diperhatikan fenomena-fenomena hukum (Achmad Ali, 1999), yaitu: (a) substansi hukum (b) struktur hukum (c) dampak dari undang-undang (cultural). ${ }^{2}$ Karena itu, maka supremasi hukum bukan hanya pada pembuatan undang-undang (law in books), tetapi pada penerapan hukum (law in action).

Law in action menjadi kebutuhan menuju pemenuhan rasa keadilan masyarakat. Dalam hal ini "kepastian hukum" menjadi prasyarat dalam negara hukum. Dengan demikian, maka prasyarat terwujudnya supremasi hukum adalah konsistensi antara law in books dan law in action. Dalam kaitan itu, Roscoe Pound (Satjipto, 1986: 266), menyatakan bahwa:

"Bagi para ahli hukum yang beraliran Sosiologis, perlu lebih memperhitungkan dari fakta-fakta sosial dalam pekerjaannya, apakah itu pembuat hukum, ataukah penafsir hukum atau penerap hukum. Ia harus memperhitungkan secara pandai fakta-fakta sosial yang harus diserap dalam hukum yang nantinya akan menjadi sasaran penerapannya. Pound menganjurkan agar perhatian lebih diarahkan kepada efek-efek yang nyata dari institusi-institusi serta doktrin-doktrin hukum. Kehidupan hukum terletak pada pelaksanaannya, karena aitu fungsi hukum adalah " $a$ tool of social engineering".

Dalam hukum Islam, telah menjadi prinsip keharusan adanya law in books dan law in action, yakni Al-Qur'an dan Hadits dijadikan sebagai dasar hukum fundamental, sedang penjabarannya dalam bentuk action telah diatur dalam fiqih, yaitu ketentuan yang mengatur perilaku dan kenyataan hidup dalam masyarakat melalui metode ijtihad.

Prinsip Hukum Islam tersebut sesungguhnya secara tidak langsung telah dipahami oleh banyak ahli hukum, seperti apa yang dikemukakan Soerjono, bahwa faktor hukum, penegak hukum, sarana hukum, masyarakat

2 Ahmad Ali, Ceramal Ilmiah, (Fakultas Hukum UMI, 1999) 
dan kebudayaan adalah faktor-faktor yang mempengaruhi penegakan hukum sebagaimana diuraikan dibawah ini $:^{3}$

\section{a. Faktor Hukum itu sendiri}

Hukum yang dimaksudkan adalah undang-undang dalam arti material. Agar supaya undang-undang mempunyai dampak yang positif, maka setidaknya harus memenuhi asas-asas yaitu : (a) undang-undang hanya boleh diterapkan terhadap peristiwa yang disebut dalam undangundang, dan terjadi setelah undang-undang itu dinyatakan berlaku; (b) undang-undang yang dibuat peguasa yang lebih tinggi mempunyai kedudukan yang lebih tinggi pula; (c) undang-undang yang bersifat khusus mengesampingkan undang-undang yang bersifat umum jika pembuatnya sama; (d) undang-undang yang berlaku belakangan, membatalkan undang-undang yang berlaku terdahulu; (e) undangundang tidak dapat diganggu gugat; (f) undang-undang merupakan suatu sarana untuk mencapai kesejahteraan spiritual dan material bagi masyarakat maupun pribadi seseorang. Tidak terpenuhi 6 asas di atas, juga karena; (a) belum adanya peraturan pelaksanaan yang dibutuhkan untuk menerapkan undang-undang; (b) ketidakjelasan arti kata-kata kesimpangsiuran dalam penafsiran serta penerapannya.

\section{b. Faktor Penegak Hukum}

Penegak hukum yang dimaksudkan adalah penegak hukum yang mencakup mereka yang secara langsung berkecimpung dalam bidang penegakan hukum yaitu (law enforcement and peace maintenance) yang meliputi hakim, jaksa, polisi, pengacara dan masyarakat, demikian pula mereka yang secara tidak langsung berkecimpung dalam bidang

\footnotetext{
${ }^{3}$ Soerjono Soekanto, Faktor-Faktor Yang Mempengaruhi Penegakan Hukum, (Jakarta: Raja
} Grafindo Persada, Cet.III, 1993), hlm.5. 
penegakan hukum, seperti pemerintah dalam arti umum, pelaku ekonomi, elit-elit politik.

Penegak hukum yang berkecimpung langsung dalam penegakan hukum, mempunyai jenjang peran tertentu, yaitu; (a) peranan yang ideal (ideal role), (b) peranan yang seharusnya (expected role); (c) peranan yang dianggap oleh diri sendiri (perceived role); (d) peranan yang sebenarnya dilakukan (actual role).

Kelemahan segi penegak hukum bisa disebabkan karena para penegak hukum tidak memahami peranannya, khususnya peranan yang seharusnya dan peranan yang sebenarnya dilakukan.

\section{c. Faktor Sarana atau Fasilitas}

Yang dimaksud sarana atau fasilitas dalam hal ini mencakup; (a) Sumber daya manusia (manpower), (b) organisasi yang baik, (c) peralatan yang memadai, dan (d) keuangan yang cukup. Keempat faktor tersebut harus terpenuhi dalam penegakan hukum demi terwujudnya tujuan hukum.

\section{d. Faktor Masyarakat}

Karena penegakan hukum berasal dari masyarakat dan untuk masyarakat dalam arti umum, maka masyarakat adalah salah satu fenomena yang sangat mempengaruhi penegakan hukum. Dari sudut sosial dan budaya, masyarakat Indonesia merupakan masyarakat majemuk (plural society) dengan sekian banyak golongan etnik dan budaya. Disamping itu, bagian terbesar penduduk tinggal di wilayah pedesaan yang berbeda gaya hidup pada wilayah perkotaan. Karena itu, para penegak hukum harus memperhatikan stratifikasi sosial, tatanan status dan peranan yang ada di lingkungan tersebut. Setiap stratifikasi sosial pasti ada dasar-dasarnya, seperti kekuasaan, kekayaan materi, kehormatan dan pendidikan. Dari pengetahuan dan pemahaman 
terhadap stratifikasi sosial tersebut, akan dapat diketahui lambanglambang kedudukan yang berlaku dengan segala macam gaya, disamping akan dapat diketahui pula faktor-faktor yang mempengaruhi kekuasaan dan wewenang beserta penerapannya di dalam kenyataan. Karena itu para pembuat dan penegak hukum harus memahami masyarakat dimana hukum akan diterapkan.

\section{e. Faktor kebudayaan}

Kebudayaan merupakan faktor yang tidak kalah pentingnya dari faktor-faktor lainnya yang mempengaruhi penegakan hukum. Sebab kebudayaan (sistem) hukum pada dasarnya mencakup nilai-nilai yang mendasari hukum yang berlaku, nilai-nilai mana merupakan konsepsikonsepsi abstrak mengenai apa yang dianggap baik (sehingga dianutnya), dan apa yang dianggap buruk (sehingga dihindari). Nilai-nilai tersebut lazimnya merupakan pasangan nilai-nilai yang mencerminkan dua keadaan ekstrim yang harus diserasikan. Pasangan nilai yang dimaksud adalah:

1) Nilai ketertiban dan ketenteraman.

Dalam keadaan sehari-hari nilai ketertiban disebut sebagai keterikatan atau disiplin, sedang nilai ketenteraman atau disiplin, sedangkan nilai ketenteraman suatu kebebasan. Keadaan tidak tenteram atau tidak bebas akan terjadi apabila; dipaksa, terpaksa, atau takut;

2) Nilai kebendaan dan keakhlakan.

Dalam kenyataan pada masing-masing masyarakat timbul perbedaan karena berbagai macam pengaruh, katakanlah pengaruh dari kegiatan modernisasi dibidang material tidak mustahil akan menempatkan nilai kebendaan pada posisi yang lebih tinggi daripada nilai keakhlakan. Penempatan nilai kebendaan pada posisi yang lebih tinggi dan lebih penting, akan mengakibatkan berbagai aspek proses hukum akan mendapat penilaian dari segi kebendaan belaka. 
3) Nilai konservatisme dan inovatisme.

Pasangan nilai konservatisme dengan nilai inovatisme senantiasa berperan di dalam perkembangan hukum, oleh karena disatu pihak ada yang menyatakan hukum hanya mengikuti perubahan yang terjadi dan bertujuan untuk mempertahankan "status quo", di lain pihak ada anggapan yang kuat bahwa hukum juga berfungsi sebagai sarana untuk mengadakan perubahan dan menciptakan hal yang baru.

\section{PEMBAHASAN}

\section{A. Faktor Yang Mempengaruhi Penegakan Hukum di Indonesia}

Berdasarkan pada rumusan, kenyataan, dan pandangan yang dikemukakan pada bagian pendahulluan diatas, maka pada dasarnya supremasi hukum di Indonesia belum dapat terwujud, yang disebabkan oleh beberapa kendala, yaitu:

\section{Kualitas Hidup Masyarakat}

Indonesia sebagai negara berkembang yang kehidupan masyarakatnya masih berada pada tingkat menengah kebawah, mengakibatkan masyarakat selalu "berdesakan" untuk memenuhi kebutuhan hidupnya yang kian meningkat. Dalam kondisi yang demikian dapat mengakibatkan terjadinya pelanggaran dan kejahatan. Rendahnya tingkat kesejahteraan masyarakat menjadi kendala besar dalam berprilaku sesuai hukum. Sebab iklim yang kurang kondusif dapat berakibat lemahnya penerapan terhadap hukum. Dalam sejarah, sebagai perbandingan, telah dipraktekkan oleh Khlaifah Umar bn Khattab r.a. bahwa: pada masa pemerintahannya terjadi masa paceklik (masa krisis) yang melanda bangsa Arab. Dalam kondisi krisis tersebut, banyak orang melakukan pelanggaran hukum, seperti 
mencuri untuk mempertahankan kehidupan keluarga mereka, padahal mereka telah memahami bahwa mencuri adalah suatu pelanggaran dalam hukum Islam yang ditetapkan Allah SWT. Sebagaimana dalam firman-Nya surah Al-Maidah ayat 38 yang artinya: "Pencuri laki-laki dan pencuri perempuan, potonglah tangan keduanya sebagai balasan perbuatan keduanya".

Pada ayat tersebut menetapkan bahwa pencuri harus dihukum potong tangan, namun dalam kenyataannya khalifah Umar bin Khattab tidak melaksanakan hukum potong tangan, bahkan beliau mengampuninya dengan alasan mereka dalam keadaan terdesak untuk memenuhi kepentingan hidupnya yang bersifat "dharuriyah".

Tindakan yang dilakukan oleh khalifah Umar bin Khattab r.a. tersebut sesuai dengan tujuan hukum diadakan oleh pembuat hukum menurut hukum Islam, sebagaimana yang dikemukakan oleh Mukhtar Yahya bahwa:4

“Tujuan hukum (syari'ah) diadakan oleh pembuat hukum (Syari') adalah untuk merealisir kemaslahatan umum, memberikan kemanfaatan dan menghindarkan kemafsadahan bagi ummat manusia, karena itu para ulama ushul mengemukakan jenis-jenis tujuan umum perundang-undangan pada 3 macam yaitu: "Alumurudh-dharuriyah, Al-umurul-hajiyah dan Al-umurul-tahsiniyah". Alumurudh-dharuriyah adalah merupakan hal-hal yang menjadi sendieksistensi kehidupan manusia yang harus ada demi kemaslahatan mereka".

Berdasarkan pada tujuan hukum menurut hukum Islam, maka tindakan kebijaksanaan yang dilakukan oleh Khalifah Umar bin Khattab R.A. diatas, merupakan tindakan dharuriyah untuk merealisir kemaslahatan masyarakat Arab yang berada pada kondisi krisis

4Yahya Muchtar dan Fatchur Rahman, Dasar-dasar Pembinaan Hukum Fiqh Islami, (Bandung: Al-Ma'arif, 1996), hlm.333. 
dimasa tersebut. Ini berarti bahwa masyarakat dapat saja melakukan pelanggaran disebabkan iklim yang kurang kondusif.

Sejalan dengan tujuan hukum Islam diatas, dalam teori ilmu hukum dikenal pula keadaan darurat (noodtoestand) yaitu suatu keadaan yang menyebabkan suatu perbuatan yang pada hakekatnya merupakan pelanggaran kaedah hukum, tetapi tidak dikenakan sanksi karena dibenarkan atau mempunyai dasar pembenaran (rechvaardigingsgrond). Sudikno Mertokusumo menyatakan bahwa: ${ }^{5}$ "keadaan darurat merupakan konflik kepentingan hukum atau konflik antara kepentingan hukum dan kewajiban hukum dimana kepentingan yang kecil harus dikorbankan terhadap kepentingan yang lebih besar. Keadaan darurat ini dapat menjadi dasar untuk menghapus hukuman. Dengan adanya keadaan darurat perbuatan yang dilakukan itu harus sungguh-sungguh dalam keadaan terpaksa untuk membela diri.....".

Bertitik tolak dari apa yang dikemukakan diatas, dapat dijadikan suatu landasan pemikitan para penguasa (pemerintah) di Indonesia untuk memahami masyarakat bangsa Indonesia yang berada pada desakan-desakan hidup dalam persaingan yang hebat (high competitive) demi terpenuhinya kebutuhan mereka, sehingga dalam kondisi yang demikian sangat sulit menegakkan hukum untuk mencapai supremasi hukum. Mengingat tujuan hukum adalah untuk kemaslahatan manusia, menjadi tugas pemerintah untuk menciptakan kualitas hidup masyarakat dengan memperbaiki sistem perekonomian, demi terwujudnya iklim yang kondusif menuju masyarakat madani.

5 Sudikno Mertokusumo, Mengenal Hukum (Suatu Pengantar), (Yogyakarta: Liberty, Edisi Ketiga, 1991), hlm.23. 


\section{Rumusan Hukum}

Salah satu faktor yang mempengaruhi penegakan hukum di Indonesia adalah rumusan hukum itu sendiri, lemahnya suatu rumusan hukum menjadi salah satu kendala untuk mencapai supremasi hukum. Kualitas suatu peraturan tidak hanya dilihat dari segi substansinya, tetapi juga harus dilihat dari segi struktur dan budayanya. Hukum tidak hanya dibuat tanpa mempertimbangkan untuk apa peraturan itu dibuat? Untuk siapa peraturan itu? Dimana peraturan itu diterapkan?

Indonesia sebagai negara bekas jajahan Hindia Belanda, berakibat sebagian besar rumusan peraturannya masih merupakan pengaruh hukum produk Hindia Belanda. Sebagai akibat tersebut peraturan yang dibuat oleh pembuat hukum di Indonesia (pemerintah) masih dipengaruhi politik hukum Hindia Belanda yang melihat tujuan aturan hukum yang yang bersifat intrumental Rumusan hukum yang bersifat simbolis tidak mungkin mempunyai dampak positif untuk mencapai supremasi hukum, sebab hukum mempunyai pengaruh yang besar terhadap tingkah laku masyarakat, sebagaimana yang dikemukakan Joseph (dalam Ahmad Ali). ${ }^{6}$ Pengaruh aturan hukum terhadap sikap warga masyarakat tergantung pula untuk tujuan apa aturan hukum bersangkutan dibuat, yang pada dasarnya dapat dibedakan pada dua tujuan yaitu:

a. Tujuan aturan hukum yang bersifat simbolis, yaitu tidak tergantung pada penerapannya agar aturan hukum tadi mempunyai efek tertentu. Misalnya larangan untuk meminum minuman keras, efek simbolis aturan hukum itu ada kalau warga masyarakat sudah yakin bahwa meminum minuman keras, tidak jadi soal, yang penting ia sudah mengetahui bahwa perbuatannya salah.

b. Tujuan aturan hukum yang bersifat instrumental, suatu aturan hukum yang bersifat instrumental apabila tujuan terarah pada suatu sikap

${ }^{6}$ Ahmad Ali, Menguak Tabir Hukum.... hlm. 75. 
perilaku konkrit, sehingga efek hukum tadi akan kecil sekali apabila tidak diterapkan dalam kenyataannya. Jadi suatu aturan hukum mengenai larangan meminum minuman keras barulah mempunyai efek instrumental jika warga masyarakat berhenti minum minuman keras, tanpa memperdulikan apakah ia berhenti karena salah ataukah ia berhenti karena merasa takut dikenakan sanksi hukum.

Memperhatikan 2 sifat tujuan aturan hukum diatas, maka rumusan hukum harus memuat nilai-nilai politik hukum dengan mempertimbangkan kondisi masyarakat bangsa Indonesia yang mempunyai kemajemukan budaya, agama dan etnik. Rumusan hukum harus mampu mengendalikan unsur-unsur yang mempunyai pengaruh dalam kehidupan masyarakat. Salah satu contoh rumusan hukum yang lemah dan tidak bersifat instrumental adalah UU Nomor 1 Tahun 1974 tentang Perkawinan, pada Pasal 2 ayat (1) ditetapkan bahwa perkawinan adalah sah apabila dilaksanakan berdasarkan agamanya dan kepercayaannya. Dari rumusan pasal tersebut dipahami bahwa perkawinan antara pihak yang berbeda agama tidak dibenarkan. Namun dalam kenyataan masih terjadi perkawinan antar agama, kenyataan tersebut disebabkan rumusan hukumnya tidak jelas apa yang dimaksudkan "berdasarkan agamanya dan kepercayaannya". Rumusan kalimat tersebut dapat menimbulkan penafsiran yang berbeda-beda para penegak hukum.

\section{Kualitas Sumber Daya Manusia (Masyarakat)}

Peningkatan mutu bukan hanya diharapkan bagi penegak hukum yang terlibat langsung dan yang tidak langsung, tetapi juga sangat diharapkan bagi masyarakat secara keseluruhan. Rendahnya tingkat pengetahuan masyarakat merupakan salah satu kendala penegakan hukum untuk mencapai supremasi hukum. Karena itu, peningkatan pengetahuan masyarakat dalam berbagai bentuk dan cara perlu ditingkatkan, sebab 
kalau tidak demikian, masyarakat sulit untuk menyesuaikan diri dengan perkembangan dunia yang semakin kompleks.

Berkenaan dengan penegakan hukum di Indonesia, peranan masyarakat sangat diharapkan keterlibatannya. Keterlibatan masyarakat tersebut memerlukan pengetahuan yang cukup memadai dalam melaksanakan aktivitas mereka sesuai bidang masing-masing. Dalam ajaran Islam dengan berdasarkan pada Al-Qur'an dan Hadits Rasullullah SAW. Menegaskan pentingnya pengetahuan (keahlian) seseorang dalam menyelesaikan masalah-masalah yang dihadapinya, sebagaimana firman-Nya surah Al-Isra' (17) ayat 36 yang artinya:

"Dan janganlah kamu mengikuti (menyelesaikan) apa yang kamu tidak mempunyai pengetahuan tentangnya, sesungguhnya pendengaran, penglihatan dan hati, semuanya itu akan dimintai pertanggung jawab".

Menelaah makna yang terkandung pada ayat diatas, menunjukkan pentingnya sumberdaya yang handal terhadap suatu persoalan yang dihadapi, sehingga Rasulullah SAW menegaskan kembali dalam sabdanya yang artinya: "Apabila suatu persoalan diserahkan kepada yang bukan ahlinya, maka tunggulah kehancurannya".

Mencermati makna yang terkandung pada hadits di atas, mengingatkan bangsa Indonesia atas kekurangan-kekurangan yang dimiliki, sehingga mereka merasa berkewajiban meningkatkan kualitas diri demi terciptanya supremasi hukum di Indonesia. Namun peningkatan kualitas sumber daya tersebut tidak mungkin tercapai jika tidak ada kepedulian dari pemerintah.

\section{B. Alternatif Pendekatan}

Berkenaan dengan tiga faktor sebagai kendala utama yang dihadapi bangsa Indonesia dalam menegakkan hukum, untuk mencapai supremasi hukum, telah menjadi penyebab terpuruknya Indonesia, baik di bidang ekonomi maupun di bidang politik dan sosial. Untuk mengantisipasi keterpurukan tersebut, maka alternatif yang dapat dipertimbangkan adalah 
"pendekatan agama dan moral". Satu-satunya jalan untuk mengantisipasi tiga kendala yang dikemukakan di atas adalah kembali pada dasar agama dan moral.

Agama dan moral (aqidah dan akhlaq) tidak dapat terpisah dalam pengamalan hukum, karena agama tanpa moral tidak dapat dilaksanakan dengan baik, sebaliknya moral tanpa agama tidak akan dapat terkendali. Dengan kata lain, perlunya keseimbangan antara zikir, fikir dan amaliyah. Sebab dengan agama akan terbentuk kualitas moral (moral intelligent) seseorang seperti sabar, jujur, adil, berani, bertanggung jawab, ikhlas. Selanjutnya melalui moral tersebut mendorong seseorang untuk melaksanakan perintah Allah SWT, secara baik dan benar sebagai pengabdian kepada-Nya, karena dengan demikianlah seseorang dapat mengendalikan diri dari segala pengaruh kehidupan materialistik, yang mendorong untuk melakukan pelanggaran hukum. Karena itu, melalui pendekatan agama dan moral seseorang dapat memotivasi dirinya untuk menjauhi segala perbuatan yang bertentangan dengan ajaran agama seperti korupsi, kolusi, nepotisme, membunuh, memberontak, minum-minuman keras dan merusak lingkungan.

Dalam Al-Qur'an, Tuhan meletakkan dasar-dasar penegakan hukum, sebagaimana yang ditegaskan dalam beberapa firman-Nya seperti Surah AnNisa ayat 58 yang artinya:

"Sesungguhnya Allah menyuruhmu menyampaikan amanat kepada yang berhak menerimanya, dan bila menetapkan keputusan hukum antara manusia hendaklah kamu tetapkan dengan adil. Dengan itu Allah telah memberikan pengajaran dengan sebaik-baiknya kepadam tentang pelaksanaan amanat dan keadilan hukum. Sesungguhnya Allah Maha Mendengar lagi Maha Melihat".

Surah An-Nisa' ayat 135 yang artinya:

"Hai orang-orang yang beriman, jadilah kamu yang benar-benar menegakkan keadilan, menjadi saksi (dalam menegakkan keadilan) karena Allah, walaupun terhadap dirimu sendiri atau ibu bapakmu atau kerabatmu, jika ia kaya atau miskin, maka Allah lebih utama (tahu) atas (kemaslahatan) keduanya. Maka janganlah kamu mengikuti hawa nafsu sehingga kamu tidak berlaku adil. Dan 
jika kamu memutarbalikkan keadilan atau menolak menjadi saksi, maka sesungguhnya Allah Maha Mengetahui terhadap apa yang kamu kerjakan".

Mencermati makan yang terkandung pada ayat diatas, maka ayat 58 adalah dasar kejujuran untuk menegakkan hukum yakni kepada siapa hukum itu ditujukan, sedang pada ayat 135 adalah dasar keberanian penegak hukum untuk menetapkan hukum tanpa melihat siapa yang dihukum. Namun untuk menegakkan keberanian dalam pelaksanaan hukum, harus ditunjang dengan sifat sabar, sebab pada dasarnya orang yang bersabar dalam menegakkan kebenaran dari Allah akan dilindungi oleh Allah SWT. Sebagaimana ditegaskan dalam firman-Nya surah Al-Baqarah ayat 153 yang artinya:

"Hai orang-orang yang beriman, mintalah pertolongan dalam menghadapi musibah dengan sikap tabah dan mengerjakan shalat. Sesungguhnya Allah bersama orang yang bersabar".

Bersabar menurut ayat diatas adalah tolak ukur keberhasilan seseorang dalam melaksanakan tugas dan aktifitasnya. Kesabaran merupakan "sejata untuk mencapai suatu kebenaran dan kesuksesan". Untuk itu Sayyidinah Ali bin Abi Thalib R.A. yang artinya: "Sabar adalah bagian dari iman, merupakan kepala dari tubuh".

Dari ungkapan Sayyidina Ali bin Abi Thalib R.A. diatas, dijadikan sebagai landasan masing-masing pihak bahwa kesabaran adalah salah satu sifat termulia dan merupakan sumber keberanian dan kejujuran, sedangkan kejujuran dan keberanian adalah inti dari penegakan hukum dalam arti supremasi hukum. Tegasnya, penegakan hukum dapa tercapai jika dalam pelaksanaannya dilandasi nilai-nilai agama dan moral, walaupun masyarakat Indonesia miskin jika agama dan moral baik, tidak akan berbuat kejahatan, katakanlah lebih baik krisis ekonomi daripada krisis agama dan moral. Sebab pelanggaran seseorang terhadap hukum tidak hanya karena faktor sanksi atau hukuman, tetapi yang utama adalah faktor konsekuensi (dosa). Tepatlah apa yang dikatakan H. Hartono Mardjono dalam persepsi mengenai penegakan hukum tanggal 6 Maret 2000 yang menyatakan bahwa 
"supremasi hukum tidak dapat terwujud karena tidak ada keberanian dan kejujuran pada penegak hukum seperti: Jaksa, hakim, polisi. Lebih lanjut beliau menyatakan "sapu kotor tidak mungkin dapat membersihkan lantai kotor".

\section{PENUTUP}

Dari uraian di atas, dapat disimpulkan bahwa kendala yang dihadapi bangsa Indonesia berkenaan dengan penegakan hukum adalah ; 1). Kualitas hidup masyarakat rendah 2). Kurang jelasnya rumusan hukum dari berbagai ketentuan perundang-undangan 3). Kualitas sumber daya manusia (masyarakat).

Demi tercapainya supremasi hukum, maka alternatif pendekatan yang pantas dilakukan adalah pendekatan agama dan moral. Karena itu, maka alternatif yang menjadi prioritas bagi pemerintahan baru sekarang adalah pembinaan akhlaq. 


\section{DAFTAR PUSTAKA}

Ali, Ahmad, Menguak Tabir Hukum (Suatu Kajian Filosofis dan Sosiologis). Chandra Pratama, Cet.I, Jakarta, 1996

1999, Ceramah Ilmiah, pada Fakultas Hukum UMI tanggal 21 September 1999

Mertokusumo, Sudikno, Mengenal Hukum (Suatu Pengantar), Edisi Ketiga, Liberty, Yogyakarta, 1991

Rasjidi, Lili, Hukum Sebagai Suatu Sistem, Remaja Rosdakarya, Bandung. 1993

Rahardjo, Satjipto, Ilmu Hukum, Alumni, Bandung, 1996

Soekanto, Soerjono, Faktor-Faktor Yang Mempengaruhi Penegakan Hukum, Cet.III, Raja Grafindo Persada, Jakarta, 1993 